\title{
PROFILE OF SEVENTEEN DIFFERENT AUTOANTIBODIES, IMMUNOGLOBULINS LEVELS, COMPLEMENT AND VITAMIN D LEVELS IN 30 BRAZILIAN PATIENTS WITH CHIKUNGUNYA INFECTION
}

Jozélio Freire de Carvalho1, *, Felipe Freire da Silva2, Licia Maria Henrique da Mota3, Carlos Ewerton Rodrigues4, Carlos Augusto Ferreira de Andrade5,6, Cezar Augusto Muniz Caldas7

1.Universidade Federal da Bahia, Salvador (BA), Brazil. 2.Universidade de São Paulo, São Paulo (SP), Brazil. 3.Universidade de Brasília, Brasília (DF), Brazil. 4.Universidade de Fortaleza, Fortaleza (CE), Brazil. 5.Fundação Oswaldo Cruz, Rio de Janeiro (RJ), Brazil. 6.Universidade de Vassouras, Rio de Janeiro (RJ), Brazil. 7.Universidade Federal do Pará, Belém (PA), Brazil.

*Corresponding author: jotafc@gmail.com

\section{INTRODUCTION}

Chikungunya virus infection (CKV) may lead to chronic arthritis in up to $40 \%$ of the patients. There are previous data regarding positive autoantibodies in CKV. The objective of this work was to evaluate systematically the presence of autoantibodies in CKV patients.

\section{MATERIALS AND METHODS}

All study participants had clinical manifestations and positivity for at least serology or real time-polymerase chain reaction (RT-PCR) for CKV. The following autoantibodies were performed: antinuclear antibodies (ANA), anti-dsDNA, anti-Sm, anti-Ro/SS-A, anti-La/SS-B, anti-U1RNP, IgG and IgM anticardiolipin, anticyclic citrullinated peptide (anti-CCP), rheumatoid factor (RF), antiribosomal P, lupus anticoagulant, anti-Jo- 1 and anti-Scl-70. $\mathrm{CH} 100, \mathrm{C} 3$ and $\mathrm{C} 4$ complement components, serum levels of immunoglobulins, C-reactive protein, erythrocyte sedimentation rate, alpha1-acid glycoprotein, antithyroglobulin, antithyroperoxidase, TRAb, 25 hydroxyvitamin D (25OHD), dengue and zika lgG and IgM antibodies were also measured.

\section{RESULTS}

Thirty CKV patients were included. Mean age was $59.1 \pm 15.7$ years, $85 \%$ female and $77 \%$ Caucasian. Disease duration was $4.9 \pm 4.0$ months. Oligoarthritis was observed in $93 \%$. Mean C-reactive protein levels were $10.1 \pm 6.8 \mathrm{ng} / \mathrm{dL}$, erythrocyte sedimentation rate $34.2 \pm 19.9 \mathrm{~mm}$ in the $1 \mathrm{st}$ hour and alpha1-acid glycoprotein $115.5 \pm 52.6 \mathrm{mg} / \mathrm{dL}$. Intramuscular betamethasone depot injection in a single dose was administered in 54\%, prednisone in 15\% and methotrexate in $23 \%$. Importantly, 1/30 (3.3\%) was positive for ANA, 4/30 (13.3\%) for RF and none was positive for anti-CCP or any other autoantibodies. Complement and immunoglobulin levels were all within the normal range. Low levels of $25 \mathrm{OHD}$ were observed in $88 \%$ of the cases.

\section{CONCLUSION}

Although we observed a high percentage of articular manifestations in CKV patients, the present study found a low frequency of autoantibodies in CKV patients. 